\title{
Letrônica
}

\section{Considerações sobre a poética do pós-modernismo}

\section{Some remarks on the poetics of postmodernism}

Samarkandra Pereira dos Santos Pimentel ${ }^{2}$

O artigo aqui apresentado é parte, com algumas alteraçoes, da tese de doutorado em Letras, defendida em 2014 na UFPB, intitulada "Paródia e mecanismo mimético em Perdição: exercício sobre Antígona", de Hélia Correia. No trabalho analisamos o drama Perdição, atentando não só para sua relaçâa com o sagrado, sob uma otica girardiana, como o considerando uma paródia pos-moderna, tal como denomina Linda Hutcheon.

(Literatura e Cultura)/ Estudos Avancados em Dramaturgia da Universidade Fedor da Pána (LPPB). <samarkandra@gmail.com>5
RESUMO: Este artigo aborda o pensamento de Linda Hutcheon (1988) acerca das contradições típicas da poética pós-moderna, que, longe de rejeitar o passado, na verdade o retoma, principalmente por meio da paródia, com o intuito de questioná-lo, desafiá-lo, mas sem descartá-lo completamente, ou, como diz esta autora, sem implodi-lo.

Palavras-chave: Linda Hutcheon; Pós-modernismo; Metaficcção historiográfica.

ABSTRACT: This article concerns what Linda Hutcheon (1988) thinks on the typical contradictions of the postmodern poetics, which, far from rejecting the past, in fact reconsiders it, mainly by means of parody, in order to question and defy it, but without having it fully dismissed, or, in the words of that scholar, without imploding it.

KEYwords: Linda Hutcheon, Postmodernism; Historiographical metafiction.

"Então, para suportar aquele dia a dia, começara a explicar a história dos países como um mero conjunto de ficç̃̃es. E inventava diálogos, introduzira novas e às vezes improváveis personagens nas cenas. Tornara-se um actor e em dias inspirados os alunos chegavam a saudá-lo com palmas. Quando lhes dava as fichas para avaliação, António apercebia-se de que as dramatizações tinham servido para que tudo fosse ainda mais confuso. Gostava de correr essa espécie de risco." 


\section{Considerações iniciais}

Cegundo Linda Hutcheon (1988), "metaficções historiográficas" são $\checkmark$ as obras narrativas da estética do pós-modernismo que têm como características recorrentes intensa autorrefletividade, referências a personagens e eventos históricos, reflexões acerca do 'fazer literário' (arte de criar...), interesse em subverter o que foi convencionado e impossibilidade de se alcançar a história, visto que ela só nos chega através da textualidade.

Porém, vale esclarecermos que as obras que se encaixavam no termo "metaficção historiográfica", consolidado por Hutcheon (1988), antes de assim denominadas, eram chamadas tanto de "adaptações romanescas da matéria histórica", segundo Caragea (2010), como também de "romance histórico apocalíptico" ou "romance histórico paródico". O termo cunhado por Hutcheon (1988), contudo, levou vantagem por "salientar os dois aspectos fundamentais desta ficção: por um lado, o seu carácter metadiscursivo e, pelo outro, a sua reação à historiografia" (CARAGEA, 2010, s./p.).

Hutcheon (1988) afirma que Cem anos de Solidão (1967), de Gabriel García Márquez (1927-1914) e Shame (1983), de Salman Rushdie (1947), são "obras paradoxais" (HUTCHEON, 1988, p. 11) e, por isso, encaixam-se bem neste perfil. 0 quê de 'paradoxal' nelas surge devido à falta de limites presentes entre gêneros, entre o literário e o não literário, tais como numa biografia ou em um relato histórico.

A obra de Garcia Márquez, por exemplo, é ambientada na mítica Macondo, uma comunidade fictícia localizada na América Latina. Valendo-se do chamado "realismo mágico" ${ }^{1}$, o autor insere nesta narrativa revoluções, corrupção, incesto, loucura, e perda de memória, tudo isso sob a ótica de

${ }^{1}$ Surgiu no início do século XX, mas só se desenvolveu na década de 60 e 70. Tem como característica marcante a apresentação do irreal como algo natural, cotidiano.
Úrsula Iguarán, uma mulher centenária e matriarca da família dos Buendía, que, com o intento "lúcido" de falar dos seus descendentes "loucos", frutos do seu incesto com o primo José Arcádio, finda por nos mostrar a realidade de uma época repleta de revoluções de propósitos questionáveis e, talvez por isso, de angústias universais.

Uma das frases iniciais da obra já nos dá uma ideia do elemento paródico mencionado por Hutcheon: "O mundo era tão recente que muitas coisas careciam de nome e para mencioná-las se precisava apontar com o dedo" (MARQUEZ, 2002, p. 7). O mundo que surge é Macondo e "as coisas" são nomeadas no decorrer da narração dos "cem anos" da família protagonista.

A referência ao Gênesis, primeiro livro bíblico, é clara. Nele, o Senhor Deus cria "um jardim em Éden" (Gen, 2:8), o paraíso, lugar de delícias, sem localização precisa no oriente, e dá a Adão o poder de a tudo nomear. Só o proíbe, sob pena de morrer, de provar a árvore da vida, a árvore do conhecimento do bem e do mal. Na obra de Garcia Márquez há também a impossibilidade de saber o que realmente ocorreu, ou seja, a impossibilidade de conhecer a História.

Assim, com base em Hutcheon, o que encontramos nas metaficções como a deste escritor colombiano são saberes históricos e o modo pelo qual chegamos até eles, problematizados pela literatura. Resulta disto o questionamento da verdade que, assim, torna-se plural.

Os criadores dessa arte pós-moderna geralmente se valem da paródia de seus parodoxos e, por meio deles, criam falsificações (por vezes, repletas de ironia) dos textos históricos, com intuito de pô-los à prova, e fazer-nos questioná-los criticamente. Portanto, essa metaficção historiográfica "é, ao mesmo tempo, intensamente auto-reflexiva e paródica, e mesmo assim procura firmar-se naquilo que constitui um entrave para a reflexividade e a paródia: o mundo histórico" (HUTCHEON, 1991, p. 12). 


\section{História e ficção: ontem e hoje}

Foi com Aristóteles que iniciamos discussões frutíferas acerca da mímesis, seu significado e sua importância, afinal de contas, no capítulo IV da sua Poética, lemos: "Imitar é natural ao homem desde a infância" (ARISTÓTELES, 1997, p. 21). Aprendemos assim a distinguir "o que foi" do "que poderia ter sido". Mas é no século XVIII que surge a preocupação com as mentiras e falsidades contidas nos relatos, preocupação esta que é retomada pela pósmodernidade "em relação à multiplicidade e à dispersão da(s) verdade(s), verdade(s) referente(s) à especificidade do local e da cultura” (HUTCHEON, 1988, p. 145). Esta postura pós-moderna diante da Verdade, que agora não é mais única e que faz da "falsidade per se" (HUTCHEON, 1988, p. 146) algo raro, torna-a "apenas as verdades alheias" (HUTCHEON, 1988, p. 146) e leva Hutcheon a corroborar, com o mero acréscimo da metaficção historiográfica, um dito de Umberto Eco que atesta existir "três maneiras de narrar o passado: a fábula, a estória heróica e o romance histórico" (HUTCHEON, 1988, p. 150).

É oportuno aqui assinalar melhor a distinção que há entre a metaficção historiográfica e o romance histórico. Hutcheon afirma, como já mencionamos, que a primeira possui uma "intensa autoconsciência em relação à maneira como tudo isso é realizado" (HUTCHEON, 1988, p.150), visto que a ficção histórica segue e/ou é modelada pelo modelo da historiografia. Já acerca do romance histórico tradicional (ou scottiano), Lukács assevera que o "pano de fundo" desse subgênero do romance é realmente a historiografia. Hutcheon alega que, enquanto os protagonistas dos romances históricos deveriam ser "um tipo, uma síntese do geral e do particular" (HUTCHEON, 1988, p. 151), "os protagonistas da metaficção historiográfica podem ser tudo, menos tipos propriamente ditos: são os excêntricos, os marginalizados, as figuras periféricas da história ficcional" (HUTCHEON, 1988, p. 151).
Ou seja, estes personagens estão inseridos no passado, mas não para sacralizá-lo de maneira nostálgica e sim para questioná-lo por meio parodístico.

Acreditamos que o mesmo vale para a literatura dramática contemporânea. Segundo Ryngaert (1998), os dramaturgos contemporâneos tratam a História nas suas peças da seguinte maneira: reconstroem a ação e os personagens nesse passado recriado, enfocam os traços locais na ambientação (traço bem romântico...), dão preferência à ótica dos personagens pequenos ou periféricos, mas o "presente da pessoa que escreve, se aparece por trás do enredo ou acena para o leitor, nunca é evocado diretamente" (RYNGAERT, 1988, p. 115).

Enfim, o olhar pós-moderno visa ser investigativo. As margens ganham relevo ao se relacionarem com o já realizado, ou melhor, com a tradição. Assim:

Quando Eliot recordou Dante ou Virgílio em The Waste Land (A Terra Desolada), podia-se pressentir, por trás desse reflexo fragmentado, uma espécie de ansioso apelo à continuidade. É exatamente isso que se contesta na paródia pós-moderna, na qual muitas vezes é a irônica descontinuidade que se revela no âmago da continuidade, a diferença no âmago da semelhança (Hutcheon 1985). Em certo sentido, a paródia é uma forma pós-moderna perfeita, pois, paradoxalmente, incorpora e desafia aquilo a que parodia (HUTCHEON 1988, p. 28).

Certos disso, os próximos três tópicos serão dedicados às definições de pós- modernismo, à exemplificação de metaficções historiográficas e à paródia pós-moderna, respectivamente.

\section{Pós-modernismo e arte pós-moderna}

Ao definir o pós-modernismo, Hutcheon (1988) afirma que ele 
[...] ensina que todas as práticas culturais têm um subtexto ideológico que determina as condições da própria possibilidade de sua produção ou de seu sentido. E, na arte, ele o faz deixando visíveis as contradições entre sua auto-reflexividade e sua fundamentação histórica (HUTCHEON, 1988, p. 15).

Assim, a arte do pós-modernismo subverte o texto histórico, mas não o rejeita. Isso ocorre porque, segundo Hutcheon (1988), a história não se tornou obsoleta: "no entanto, ela está sendo repensada - como uma criação humana” (HUTCHEON, 1988, p. 34). Dessa forma,

[...] não podemos conhecer o passado, a não ser por meio de seus textos: seus documentos, suas evidências, até seus relatos de testemunhas oculares são textos. Até mesmo as instituições do passado, suas estruturas e práticas sociais, podem ser consideradas, em certo sentido, como textos sociais (HUTCHEON, 1988, p. 34)

Ciente de que não pode fugir de questões econômicas, como o capitalismo, ou ideológicas, como o 'humanismo liberal', essa cultura pós-moderna questiona e problematiza seu tempo "a partir de dentro" (HUTCHEON, 1988, p. 15), questiona o que "Barthes (1973) chamou de "dado" ou de "óbvio" em nossa cultura” (HUTCHEON, 1988, p. 15).

Hutcheon (1988) reconhece que isso pode gerar uma "retórica apocalíptica", pois "o pós-moderno não assinala uma mudança utópica radical nem uma lamentável queda em direção aos simulacros hiper-reais. Não existe - ou ainda não existe -, de forma alguma, nenhuma ruptura" (HUTCHEON, 1988, p. 16). Assim, torna-se recorrente nas definições que surgem do pós-modernismo a presença de termos negativos, tais como "descontinuidade, desmembramento, deslocamento, descentralização, indeterminação e antitotalização" (HUTCHEON, 1988, p. 19). Porém, ela continua:
O que todas essas palavras fazem, de forma literal (exatamente com seus prefixos, que negam o compromisso - des, in e anti), é incorporar aquilo que pretendem contestar - conforme o faz, suponho, o próprio termo pósmodernismo (HUTCHEON, 1988, p. 19).

Com a citação acima, fica-nos cada vez mais claro o quão contraditório é o pós-modernismo, que "usa e abusa, instala e depois subverte, os próprios conceitos que desafia" (HUTCHEON, 1988, p. 19) e isso não se restringe somente ao romance, gênero eleito por Hutcheon, mas vale para toda a arte pós-moderna, ou mesmo a filosofia, a teoria estética, a psicanálise, a linguística ou a historiografia (HUTCHEON, 1988, p. 19).

Porém, como acima visto, esse retorno ao passado visa ser sempre crítico, e nunca nostálgico. É neste ponto que percebemos o papel preponderante da ironia nesta poética pós-moderna, pois, ao contrário do que ocorre no modernismo, o pós-modernismo

[...] se recusa a propor qualquer estrutura ou, como a denomina Lyotard (1984a), qualquer narrativa-mestra - tal como a arte ou o mito - que serviria de consolo para esses modernistas. Ele afirma que tais sistemas são de fato atraentes, talvez até necessários; mas isso não os torna nem um pouco menos ilusórios (HUTCHEON, 1988, p. 23).

A ilusão dessas narrativas mestras ou metanarrativas, como nomeia Lyotard, em A condição pós-moderna (1979), consiste no seu papel totalizador, estável e na sua capacidade legitimadora. Já as narrativas da pósmodernidade seriam "narrativas menores e múltiplas que não buscam (nem obtêm) qualquer estabilização ou legitimação universalizante" (HUTCHEON, 2002 , s./p.), ou seja, o que ocorre é a perda da grande narrativa unificadora e, assim, o consenso é que seria uma ilusão.

O mesmo se aplica à dramaturgia contemporânea. Ryngaert (1998) constata: 
Nossa sociedade se importa mais com a originalidade do que com a herança e isso, poderíamos acrescentar, na medida em que, para a obra de arte, se trata menos de ser entendida em termos de ruptura. Ao passo que os dramaturgos clássicos retomavam as grandes narrativas fundadoras, míticas ou morais, reelaborando suas fontes na perspectiva de valores de suas sociedades, os dramaturgos pós-modernos e seus leitores "sabem que a legitimação só pode vir de sua prática linguística”, diz ainda Lyotard (RYNGAERT, 1998, p. 84).

Ao refletir sobre os autores contemporâneos que retomam a tradição clássica nos seus dramas, Ryngaert (1998) observa que

Eles ainda se referem às grandes narrativas do passado apenas para melhor dissolvê-las na multiplicidade dos pontos de vista ou para deixar pairar uma maior dúvida sobre o sentido do mito e sua utilidade atual (RYNGAERT, 1998, p. 84).

Hutcheon (1988) já havia observado atitude semelhante por parte dos escritores pós-modernos que, ao se apropriarem da noção de consenso, a transforma em "ilusão de consenso" (HUTCHEON, 1988, p. 24), usando e abusando "das próprias estruturas e valores que desaprova” (HUTCHEON, 1988, p. 142). Assim, o pós-modernismo demonstra

[...] que todos os reparos são criações humanas, mas que, a partir desse mesmo fato, eles obtêm seu valor e também sua limitação. Todos os reparos são consoladores e ilusórios. Os questionamentos pós-modernistas a respeito das certezas do humanismo vivem dentro desse tipo de contradição (HUTCHEON, 1988, p. 24)

Portanto, a arte pós-moderna, essencialmente contraditória, visa "desmitificar nossos processos cotidianos de estruturação do caos, de concessão ou atribuição de significado" (HUTCHEON, 1988, p. 24). Não é à toa que essa ganha ares apocalípticos...

\section{Metaficções historiográficas: exemplos}

Hutcheon, dentre os vários exemplos que utiliza, cita um retirado de Shame (1983, p. 28), de Salman Rushdie, onde o narrador dessa metaficção historiográfica "se volta declaradamente para as possíveis objeções contra sua posição de insider/outsider que, da Inglaterra - e em inglês -, escreve sobre os acontecimentos do Paquistão" (HUTCHEON, 1988, p. 144):

Estrangeiro! Transgressor! Você não tem o direito de falar desse assunto! (...) Eu sei: ninguém jamais me prendeu [como fizeram com o amigo sobre o qual ele acabou de escrever]. Nem é provável que o façam. Ladrão! Pirata! Nós rejeitamos sua autoridade. Nós o conhecemos, com sua língua estrangeira que o envolve como se fosse uma bandeira: falando a nosso respeito em sua língua bífida, o que pode você dizer além de mentiras? Eu respondo com outras perguntas: Será que a história deve ser considerada propriedade exclusiva de seus participantes? Em que tribunais estão afixados esses direitos, quais são as comissões de fronteiras que mapeiam os territórios? (HUTCHEON, 1988, p. 144).

Algo similar ocorre em diversas obras da escritora portuguesa Hélia Correia (1949), por exemplo, em Soma (1987), obra escrita na mesma década dos textos de Salman Rushdie e de Linda Hutcheon.

De início, em Soma, já encontramos uma referência clara ao romance Admirável Mundo Novo (1932), de Aldous Huxley (1894-1963), contida não só no título como em outro elemento paratextual, a sua primeira citação, que é retirada daquele romance inglês. Mas as semelhanças são nuançadas, porque na novela de Hélia Correia não há nada que se aproxime de uma obra de ficção científica, mas os elementos da obra de Huxley estão presentes: pessoas que vivem agrupadas, de acordo com algo semelhante a uma casta, que tomam soma, a "droga perigosa” (HUXLEY apud CORREIA, 1887, p. 9), mas com "vários efeitos benéficos" (HUXLEY apud CORREIA, 1887, p. 9) em relação aos quais "nem Indra, o deus do céu, está imune" (HUXLEY, 
apud CORREIA, 1887, p. 9), e que não possuem ética religiosa ou valores morais que imperam na sociedade em que estão inseridos.

Seu protagonista é António Eliseu, um professor de história de 40 e poucos anos, divorciado e com um filho com quem pouco convive. As crises existenciais da personagem são ressaltadas. Buscando uma saída para o sentimento de ser um estranho onde quer que esteja, refugia-se da sua vida antiga juntando-se a um grupo de jovens alienados, partindo, posteriormente, para uma casa misteriosa. Para o que pretendemos mostrar, faz-se premente transcrever um trecho do livro no qual o protagonista, ciente da ignorância dos seus jovens amigos, falava-lhes - de maneira bem particular - sobre os acontecimentos históricos:

Então, para suportar aquele dia a dia, começara a explicar a história dos países como um mero conjunto de ficç̃es. E inventava diálogos, introduzira novas e às vezes improváveis personagens nas cenas. Tornara-se um actor e em dias inspirados os alunos chegavam a saudá-lo com palmas. Quando lhes dava as fichas para avaliação, António apercebia-se de que as dramatizações tinham servido para que tudo fosse ainda mais confuso. Gostava de correr essa espécie de risco.

E ali, no seguimento de um acaso, dispôs a relatar a Jonas e aos outros como nascera a vida, os rastros da pré-história. Ante ouvidos atentos, fez avançar o homem pelas suas cidades e pelos desertos. Como um naturalista, talhando em cada época um corte vertical, revelava os diversos sedimentos, as diferentes camadas de células hostis que se entrechocavam, devorando-se, calcando aos pés as mais debilitadas e erguendo teorias de deuses e sistemas que - essa era a mais espantosa, a mais enigmática das observações - faziam sentido. De certa perspectiva, tudo se resumia a zangas de famílias; de uma outra, tratava de afectos excessivos, desmesurado orgulho ou louco apego à terra. E, tão abaixo disto como o reino das trevas, as densas multidões, as densas multidões de gente seminua, arquejando, no peso de um trabalho infindável, nutrindo-se umas vezes do ódio, outras da fé, pronta a provocar estragos notáveis sempre que lhes franqueiem acesso à superfície (CORREIA, 1987, p. 59-60).

Como percebemos, há em Soma uma crítica mordaz ao estilo de vida nele apresentado, pois os reparos humanos propostos são claramente desacreditados porque, como bem assinalou Hutcheon (1988), são ilusórios. Esta crítica também é feita na obra de 1932 de Huxley que, segundo Seabra Pereira (2008), mostra-nos um verdadeiro engodo utópico "de programação do mundo perfeito e de titanismo² mecânico" (PEREIRA, 2008, p. 356).

Também podemos destacar algo bastante relevante no excerto de Soma acima: a falsificação declarada da história. Carageia (2010) denomina este tipo de metaficção historiográfica de "ficção contrafactual", por alterar "o curso dos acontecimentos, tal como este foi estabelecido pela investigação histórica" (CARAGEIA, 2010, s./p.). Assim, a

[...] ideia básica sobre a qual assenta este tipo de ficção é a de que qualquer situação histórica implica uma multidão de possibilidades divergentes que excedem/transbordam o curso efectivo dos acontecimentos. Sob este ângulo, o progresso da história apresenta-se como um desgaste não só de vidas humanas, mas de opções e oportunidades, uma vez que a escolha de uma única possibilidade supõe necessariamente a eliminação das outras alternativas. As histórias contrafactuais são deste ponto de vista outras tantas tentativas de recuperar as possibilidades perdidas e a história no seu todo (real e potencial) apresenta-se como um labirinto de sendas que se bifurcam segundo a sugestiva metáfora de Borges (CARAGEIA, 2010, s./p.).

Hutcheon (1988) destaca que nas metaficções historiográficas é comum encontrarmos uma tentativa de instituir uma relação dialógica entre o presente e o passado. Isto ocorre porque a autora parte da ideia de que o total conhecimento histórico é ilusório e que, como observa Caragea (2010),

[...] o fingimento deve ser abandonado a favor de um reconhecimento honesto de que se fala a partir do presente e de que o passado considerado não existe por si próprio, mas é aquele que este presente construiu para o seu próprio uso e em função de desejos e intenções muitas vezes inconfessáveis (CARAGEA, 2010, s./p.).

2 Conforme lemos no Infopédia: "Segundo a mitologia, Titã era um gigante que tentou escalar os céus. O titanismo é o noço do herói romântico, semidivino e céus. 0 titanismo é o traço do heról romântico, semidivino e semi-humano, que desafia os limites que 0 titânica define a próp míticas como Prometeu" (INFOPÉDIA, 2003-2014, s./p.). 


\section{Paródia pós-moderna}

Antes de iniciarmos nossas considerações acerca da paródia pósmoderna, é premente que façamos algumas breves considerações sobre a paródia e outro recurso de imitação que geralmente é confundido com ela: o pastiche.

Hutcheon afirma que os criadores de uma arte pós-moderna se valem da paródia como recurso. Jameson afirma algo parecido, mas ele diz que o recurso usado é o pastiche, que, para ele, é uma paródia vazia do passado. Ceia, por sua vez, afirma que a "paródia é um jogo de traição premeditada do sentido. Não há paródia sem subversão do sentido" (CEIA, 2010, s./p.). Já Charaudeau e Maingueneau (2006) afirmam que o "pastiche é uma prática de imitação que se distingue da subversão* paródica por seu objetivo lúdico, não militante" (CHARAUDEAU e MAINGUENEAU, 2006, p. 371). Assim, conclui Ceia (2010),

[...] impõem-se também condições diferentes de referenciação à paródia e ao pastiche: este vive na dependência e obediência ao modelo imitado, ao passo que a paródia é tanto mais efectiva quanto maior for a distanciação em relação ao género do modelo parodiado (CEIA, 2010, s/p).

É comum associarmos a paródia ao ridículo e à zombaria, ou seja, ao cômico. Ceia (2010) afirma que estas características são condições para a paródia. Hutcheon (1988), entretanto, discorda dessa afirmação:

[...] quando falo em 'paródia', não estou me referindo à imitação ridicularizadora das teorias e das definições padronizadas que se originam das teorias de humor do século XVIII. A importância coletiva da prática paródica sugere uma redefinição da paródia como uma repetição com distância crítica que permite a indicação irônica da diferença no próprio âmago da semelhança. $\mathrm{Na}$ metaficção historiográfica, no cinema, na pintura, na música e na arquitetura, essa paródia realiza paradoxalmente tanto a mudança como a continuidade cultural: o prefixo grego para- pode tanto significar 'contra' como 'perto' ou 'ao lado' (HUTCHEON, 1988, p. 47).
Como vemos, Hutcheon discorda de Ceia, pois crê que a paródia pode homenagear ${ }^{3}$ o texto anterior e, assim, a "inclusão da ironia e do jogo jamais implica necessariamente a exclusão da seriedade e do objetivo na arte pós-modernista" (HUTCHEON, 1988, p. 48).

Ela destaca o papel preponderante (e contraditório) da paródia nas obras de arte pós-modernas: "são todas visivelmente históricas e inevitavelmente políticas, exatamente por serem paródicas em sua forma" (HUTCHEON, 1988, p. 43).

Como já mostramos, essas obras:

[...] usam e abusam, estabelecem e depois desestabilizam a convenção de maneira paródica, apontando autoconscientemente para os próprios paradoxos e o caráter provisório que a elas são inerentes, e, é claro, para sua reinterpretação crítica ou irônica em relação à arte do passado (HUTCHEON, 1988, p. 43).

Hutcheon afirma que o "passado como referente não é enquadrado nem apagado", pois, "ele é incorporado e modificado, recebendo uma vida e um sentido novos e diferentes" (HUTCHEON, 1988, p. 45). Isso ocorre porque a paródia se encontra na história social dentro de um contexto social, visto que é nele que ela se projeta e se constrói.

Ao diferenciar como se dá a escrita paródica no modernismo e no pósmodernismo, Hutcheon (1988) afirma:

Sem ter nada do iconoclasmo do modernismo, esse projeto paródico demonstra sua consciência crítica e seu amor à história com a atribuição de novos sentidos a velhas formas, embora muitas vezes o faça com ironia. Evidentemente, nesse caso estamos lidando com formas e ornamentação clássicas, mas com um novo e diferente enfoque: não há nenhuma decoração de fabricação manual (não se trata de uma exaltação da individualidade romântica, ou mesmo do artesanato

${ }^{3}$ Sangsue (1994), em seu estudo panorâmico acerca da paródia, constata que a crítica não foi pioneira por constatar a possibilidade de continuidade na paródia, isto coube a Margaret Rose, com Parody/ Meta-fiction (1979), porém, Hutcheon foi hábil em prolongar esta reflexão. 
gótico). A ornamentação está presente, mas é um novo tipo de ornamentação, que na verdade participa da impessoalidade e da padronização mecânicas do modernismo (HUTCHEON, 1988, p. 53-54).

Hutcheon (1988) destaca que a paródia do passado traz referências que são captadas pelo público (diferente do que ocorre com a intertextualidade ${ }^{4}$ ), já na paródia pós-moderna, é permitido "falar para um discurso a partir de dentro desse discurso, mas sem ser totalmente recuperado por ele" (HUTCHEON, 1988, p. 58). Isso ocorre porque a arte pós-moderna problematiza acerca da nossa acessibilidade "à natureza concreta dos acontecimentos" (HUTCHEON, 1988, p. 61). A crítica argumenta que é por isso que a paródia parece ter se tornado "a categoria" daquilo que ela chama "de "ex-cêntrico", daqueles [tipos] que são marginalizados por uma ideologia dominante" (HUTCHEON, 1988, p. 58).

A autora vêa paródia como paradoxalmente conservadora e revolucionária ao mesmo tempo e é isso que a torna "uma forma apropriada de crítica para o pós-modernismo, que já é paradoxal em sua inserção conservadora e sua subsequente contestação radical com relação às convenções" (HUTCHEON, 1988, p. 169). Cem Anos de Solidão (1967), de Gabriel García Márquez, $O$ Tambor (1959), de Günter Grass (1927), são bons exemplos de metaficções historiográficas que

[...] utilizam a paródia não apenas para recuperar a história e a memória diante das distorções da 'história do esquecimento' (Thiher 1984, 202), mas também, ao mesmo tempo, para questionar a autoridade de qualquer ato de escrita por meio da localização dos discursos da história e da ficção dentro de uma rede intertextual em contínua expansão que ridiculariza qualquer noção de origem única ou de simples causalidade (HUTCHEON, 1988, p. 169).

\footnotetext{
${ }^{4}$ O conceito de intertextualidade foi cunhado por Kristeva (1969), ele consistiria na aparição de textos anteriores em um texto. Barthes o ampliou ao afirmar que: "Todo texto é um intertexto; outros estão presentes nele, en niveis varíveis, sob formas mais ou menos rexón campo automáticas, feitas sem aspas (1973)" (CHARAUDEAU \& MAINGUENEAU, 2006, p. 289).
}

Assim, quando a paródia se liga à sátira, "certamente pode assumir dimensões mais precisamente ideológicas” (HUTCHEON, 1988, p. 169):

0 'ex-cêntrico' - tanto como off-centro quanto como descentralizado - passa a receber atenção. Aquilo que é 'diferente' é valorizado em oposição à 'nãoidentidade' elitista e alienada e também ao impulso uniformizador da cultura de massa. E no pós-modernismo americano, o diferente vem a ser definido em termos particularizantes como os de nacionalidade, etnicismo, sexo, raça e escolha sexual. A paródia intertextual dos clássicos canônicos americanos e europeus é uma das formas de se apropriar da cultura dominante branca, masculina, classe-média, heterossexual e eurocêntrica, e reformulá-la - com mudanças significativas. Ela não rejeita essa cultura, pois não pode fazê-lo. 0 pós-modernismo indica sua dependência com seu uso do cânone, mas revela sua rebelião com seu irônico abuso desse mesmo cânone (HUTCHEON 1988, p. 170).

O uso da paródia sob a forma da sátira, conforme observa Hutcheon, assemelha-se ao empregado muitos séculos antes pelo contador de histórias e fabulista grego Esopo (620 a.C.-564 a.C.), o "pai da fábula”, ou mesmo por seus seguidores Fedro (15 a.C.-50 d.C.), La Fontaine (1621-1695), já que o “'consagrado discurso' intertextual” vem "embutido num comentário social sobre a perda da relevância de valores tradicionais na vida contemporânea" (HUTCHEON, 1988, p. 170). Assim, surgem personagens tais como uma lebre, uma tartaruga, um menino ou mesmo um caniço, com o intuito de nos falar do caráter vão e estúpido de muitas ações humanas. George Orwell (1903-1950) se valeu de uma "estratégia" similar em Animal Farm (1945), uma sátira política, sob a forma de fábula, que mostrava a impossibilidade de se habitar um mundo inabitável. Nesse contexto, outro exemplo de Hutcheon é a paródia do clássico A Christmas Carol (1843), de Charles Dickens (1812-1870), realizada por Ismael Reed em The Terrible Twos (1982), em que $o$ 
[...] Presidente dos Estados Unidos, um ex-modelo fútil e alcoólatra, é regenerado por uma visita de São Nicolau, que o conduz numa viagem através do inferno, representando o papel de Virgílio para seu Dante e o de Marley para seu Scrooge (HUTCHEON, 1988, p. 171)

Nesta obra, o personagem avarento Scrooge encarna a "América yuppie de 1980" (HUTCHEON, 1988, p. 171). Com esses exemplos, fica mais fácil entender por que, conforme Ceia (2010), para melhor fazer a distinção entre paródia e sátira, é preciso "atentar no tipo de ulceração" que a primeira produz no seu modelo:

[...] o ataque parodístico é quase sempre feito de forma travestida ou simulada, protegido pelo véu da ironia; o ataque satírico é desvelado e não precisa de nenhuma protecção retórica, porque de alguma forma se concretiza por uma atitude de desprezo completo em relação ao objecto satirizado. Ao deformar, a paródia quer mostrar a falência de um modelo original deixando em aberto uma possibilidade de regeneração pelo próprio exemplo parodiado; ao censurar, a sátira não admite qualquer possibilidade de regeneração do objecto satirizado, interessando-lhe apenas a destruição como modelo desse objeto (CEIA, 2010, s./p.).

Já sobre o uso de textos consagrados por parte de autores com uma clara agenda política, tais como as feministas ${ }^{5}$ e os estudiosos das relações étnicoraciais, Hutcheon observa que a intertextualidade irônica é tanto ideológica como estética e:

Para esses autores, a paródia é mais do que uma simples estratégia essencial pela qual a 'duplicidade' se revela (Gilbert e Gubar 1979a, 80); é uma das principais maneiras pelas quais as mulheres e outros ex-cêntricos usam e abusam, estabelecem e depois desafiam as tradiç̃es masculinas na arte. Em A Cor Púrpura, Alice Walker recorre a versões irônicas de conhecidos contos de fadas: Branca de Neve, O Patinho Feio, A Bela Adormecida, etc. Mas a importância das paródias só fica evidente quando o leitor percebe a inversão do sexo e raça efetuada por sua ironia: o mundo em que depois ela vive feliz para sempre é feminino e negro (HUTCHEON, 1988, p. 175).

5 Vide: "A incredulidade a respeito das metanarrativas: articulando pós-modernismo e feminismos" (2002), também de Hutcheon.
Dito isto, percebemos a incompatibilidade entre a paródia realizada por aqueles que possuem o propósito político, como alguns escritores cujo foco são as relações étnico-raciais ou feministas, com a proposta pós-moderna exposta por Hutcheon. E o motivo é claro: tanto o Feminismo como os movimentos de Negritude ${ }^{6}$ necessitam do conceito de 'verdade', portanto, ambos têm fortes motivações políticas e o pós-modernismo "é certamente político, mas é politicamente ambivalente, duplamente envolvido com cumplicidade e crítica, subvertendo e mantendo ao mesmo tempo a posição metanarrativa" (HUTCHEON, 2002, s./p.).

Hutcheon faz uma observação relevante acerca da nossa recepção dos paradoxos:

Em geral, os paradoxos podem causar prazer ou problemas. Dependendo da constituição de nosso temperamento, seremos seduzidos por sua estimulante provocação ou perturbados por sua frustrante ausência de resolução. No pósmoderno não existe dialética: a auto-reflexão se mantém distinta daquilo que tradicionalmente se aceita como seu oposto - o contexto histórico-político no qual se encaixa (HUTCHEON, 1988, p. 12).

Frota (s/d) cita Aragão (1980, p. 19), que corrobora Hutcheon ao destacar a postura paradoxal do parodiador que recusa o parodiado, mas também o assume. Isso se dá ao destruir o modelo para depois recriá-lo. Assim,

[...] nesta recusa dos modelos literários, a paródia está denunciando que a estrutura já se esgotou (...) e que é preciso esvaziá-la para preencher com algo novo. Pois quando um sistema ideológico e literário fica saturado, necessita de um esvaziamento para possibilitar um novo questionamento. 0 parodista desmistifica todo o sistema sobre o qual os mitos se apóiam, questiona a ideologia, mas não traz respostas, e sim, procura provocar reflexão no leitor (FROTA, s./d., s./p.)

${ }^{6}$ Negritude foi o nome dado por Aimée Césaire, na década de 30, e se tornou uma corrente de estudos literán, surgido na França, cujo propósito na dén br/040/40damasio. htm>. Acesso em: 10 mar. 2013. 
Assim, decorrem também deste 'assassinato' dos modelos literários tradicionais, por meio de sua paródia, "novas possibilidades de realização" (FROTA, s./d., s./p.).

Porém, é premente lembrarmos que, às vezes, há a zombaria que 'castiga os costumes' e, igualmente, aproxima a paródia da sátira, quando percebemos o ridículo típico do cômico. Basta lembrarmos de Gil Vicente (1465-1537). Retomando a máxima horaciana, ridendo castigat mores, o objetivo do dramaturgo português era castigar os costumes através do riso, entretanto, o resultado disso é que em muitas das (ou em todas as) suas paródias, farsas e sátiras, há um manifesto descontentamento com o desconcerto do mundo. Basta lembrarmos o que ocorre na sua trilogia das barcas (Auto da barca do inferno, Auto da barca do Purgatório, Auto da barca da Glória): ninguém, excetuando o parvo Joane, vai ao paraíso. 0 parvo é salvo porque, como bem observa Moreira (2005),

[...] ele não é representante de nenhum estrato social ou grupo profissional: ele tem uma função cômica, principalmente pela irreverência e pelos disparates que profere, desencadeando o riso, em situações que não dizem respeito a sua pessoa, principalmente satirizando, por meio da comicidade dos seus ditos, alguns personagens que têm a presunção de se considerarem merecedoras do Paraíso e, portanto, de embarcarem na barca da glória (MOREIRA, 2005, p. 49-50).

Enfim, é com seu latim "macarrônico" que Joane acusa a todos ao expô-los tão ridículos. Ao fim de tudo, o bobo não tinha por que não se salvar: o Anjo, personagem que consente o embarque ou não na Barca da Glória, o vê como um ser ingênuo e sem a malícia necessária para ser condenado à barca do Inferno. Em suma, os costumes são devidamente castigados e o riso prevalece.

\section{Considerações finais}

Cremos que foi possível mostrar quão contraditória e desafiadora é a poética do pós-modernismo, uma arte que se vale da paródia para questionar criticamente a História, embora pareça, por vezes, ter como objetivo somente destruí-la... Os diversos prefixos negativos e os vários pontos de vista que não indicam caminho algum, como vimos, contribuem para esta conclusão. Porém, enfatizamos que, nem sempre, a paródia pós-moderna visará implodir o texto parodiado, pois, às vezes, também terá como objetivo homenageá-lo. Para nós, esta foi uma das melhores lições deixadas por Hutcheon.

\section{Referências}

ARISTÓTELES, HORÁCIO, LONGINO. A poética clássica. Tradução de Jaime Bruna. 7. ed. São Paulo: Cultrix, 1997.

BÍBLIA DE JERUSALÉM. São Paulo: Paulus, 2004.

CARAGEA, Miora. Metaficção historiográfica. In: E-Dicionário de termos literários de Carlos Ceia. 2010. Disponível em: <http://www.edtl.com.pt/index.php?option=com mtree\&task=viewlink\&link_id=1572\&Itemid=2>. Acesso em: 09 mar. 2013.

CEIA, Carlos. Paródia. In: E-Dicionário de termos literários de Carlos Ceia. 2010. Disponível em: <http://www.edtl.com.pt/index.php?option=com_mtree\&task=viewlink\&link $\mathrm{id}=353 \&$ Itemid=2> . Acesso em: 22 out. 2012.

CHARAUDEAU, Patrick; MAINGUENEAU, Dominique. Dicionário de análise do discurso. Tradução de Fabiana Komesu. 2. ed. São Paulo: Contexto, 2006.

CORREIA, Hélia. Soma. Lisboa: Relógio d'agua Editores, 1987.

FROTA, Adolfo José de Souza. A paródia em “Conto barroco ou unidade tripartita”. s./d. Disponível em: <http://www.dacex.ct.utfpr.edu.br/8adolfo.htm>. Acesso em: 22 out. 2012. HUTCHEON, Linda. A poética do pós modernismo. Rio de Janeiro: Imago, 1988.

A incredulidade a respeito das metanarrativas: articulando pós-modernismo e feminismos. Tradução de Margareth Rago. Labrys, estudos feministas, n. 1-2, jul.- 
dez. 2002. Disponível em: <http://www.tanianavarroswain.com.br/labrys/labrys1_2/ linda1.html>. Acesso em: 26 nov. 2012.

MÁRQUEZ, Gabriel García. Cem anos de solidão. 52. ed. Rio de Janeiro: Record, 2002.

MOISÉS, Massaud. Dicionário de termos literários. São Paulo: Cultrix, s./d.

Dicionário de termos literários. 12. ed., revista e ampliada. São Paulo: Cultrix, 2004.

MOREIRA, Zenóbia Collares. Humor e crítica no teatro de Gil Vicente. Natal, RN: Econômica, 2005.

PLAUTO \& TERÊNCIO. A comédia latina: Anfitrião, Aululária, Os cativos, O gorgulho, Os adelfos, O eunuco. Prefácio, seleção, tradução e notas de Agostinho da Silva. Rio de Janeiro: Ediouro, s./d.

RYNGAERT, Jean-Pierre. Ler o teatro contemporâneo. São Paulo: Martins Fontes, 1998. SANGSUE, Daniel. La Parodie. Paris: Hachete Supérier, 1994.

SEABRA PEREIRA, José Carlos. Alotropia e desejo de plenitude na modernidade ocidental. In: X Semana Cultural da UC. 2008.

Frágil contingência e terna solicitude na literatura contemporânea. In: Revista Portuguesa de Bioética, n. 6, p. 349-368, dez. 2008.

Recebido em 21/10/2015

Aceito em 04/02/2016. 